\title{
Assess Teaching Skill with the use of Microteaching Tool among Post Graduate Nursing Students
}

\author{
Madhuri Shambharkar, Achita Sawarkar, Jaya Khandar and Vaishali Tembhare \\ Community Health Nursing, SRMMCON, Sawangi (M), Wardha, India \\ Corresponding author email:mnnaik91@gmail.com
}

\section{ABSTRACT}

Teaching is a process which facilitates learning by encouraging learners to think. Feel and do. Teaching skill can be defined as teacher behaviors which are specially effective in bringing about desired changes in students. Teaching is an interactive process which taken place between teacher and students to influence each other. Teaching is a task of a teacher who not only improves information but also motivates, guides, helping and encourages students to learn. Objectives: 1) Sensitization of 1st year nursing post graduate students towards microteaching teaching. 2)To evaluate the teaching skill of nursing post graduate students through micro-teaching approach. Methods and Materials: Cross sectional descriptive research design was used. Twenty post graduate MSc 1st year nursing students were selected by non probability purposive sampling technique. Standardized evaluation format of microteaching was used to assess teaching skill. Findings shows that (0\%) had poor level of teaching skill, (12\%) had average level of teaching skill, (48\%) had good level of teaching skill and (20\%) had very good level of teaching skill and no one had excellent level of teaching skill. The minimum score was 10 and the maximum score was 19.5, the mean score for the test was $14.50 \pm 2.57$ and mean percentage of teaching skill 58\%. Microteaching is a teaching technique that helps the budding teachers to improve their teaching skill. Microteaching helps the trainee teachers to improve their confidence level, communication and self confidence.

KEY WORDS: TEACHING SKILL, MICROTEACHING, TEACHING, TECHNIQUE.

\section{INTRODUCTION}

Teaching is a process which facilitates learning by encouraging learners to think. Feel and do. ("JAYPEE BROTHERS: Book Details," n.d.) The teacher should create such a environment that student should be eager to attend the class. Teacher responsibility is to teach the students in a simple language so the learning becomes easy for them. Teacher should have to give examples that shold be based on real life situations and they can apply their knowledge. Teaching is an interactive process which taken place between teacher and students to influence each other. ("How to teach?," n.d.) Teaching is a task of a teacher who not only improves information but also motivates, guides, helping and encourages students to learn. Is both science and art, SCIENCE as it based on psychological

Biosc Biotech Res Comm P-ISSN: 0974-6455 E-ISSN: 2321-4007

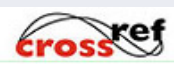

Identifiers and Pagination

Year: 2021 Vol: 14 No (9) Special

Issue Pages: 386-388

This is an open access article under Creative

Commons License Attribn 4.0 Intl (CC-BY).

DOI: $h t t p: / / d x$.doi.org/10.21786/bbrc/14.9.72 research that identifies cause and effect relationship between teaching and learning, ART, as it shows how those relationships are implemented in successful and artistic teaching. (Rimm-Kaufman et al., n.d.). Teaching skill can be defined as a teacher behaviors which are specially effective in bringing about desired changes in students.("Learning and Teaching Nursing (Fourth Edition) by B. Sankaranarayanan,B. Sindhu,” n.d.).

The aim of teaching skills as a method is to supply a clear, practical form of guide to those efficient teaching skills/ platform skills which most of the teachers acquire only through years of experience.(Basavanthappa, 2009) Becoming a better teacher is something all educators should be concerned with. Good teachers are effective classroom managers and communicators who can adapt to a variety of learning styles and effectively instruct a large percentage of the class. Improvement of teaching in the classroom can be obtained by putting together a plan of action and following it through. Teachers who make the extra effort to improve their teaching can make a significant impact on the lives of students. "how to improve teaching and learning in the classroom," 2020).

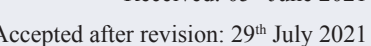

Article Information

Received: $05^{\text {th }}$ June 2021 cepted after revision: $29^{\text {th }}$ July 2021 
It teaches students how to give and receive constructive feedback and provides to better understand the content of education lessons. One more benefit to microteaching is that new staff have an opportunity to better understand the content they are expected to teach.("Outdoor Education School Science Camps California,” 2013) In microteaching the trainee teacher get the chance to improve teaching skill. They will do their presentation by using microteaching technique of teaching in peer classroom. After completion the class student will get feedback it will help to know their mistakes they done in teaching. Constructive feedback helps to students to improve to improve their skill. Practice makes the person perfect.

\section{METHODOLOGY}

Cross sectional descriptive research design was used in this study. The study was conducted in Smt. Radhikabai Meghe Memorial College of Nursing in Sawangi Meghe, Wardha. The population of the study was, 1st year MSc nursing students and the sample size was 20. The sampling technique used was non-probability purposive sampling technique. First topic were given to all twenty students for preparation of microteaching before two days of presentation. All 20 students had taken the class on peer group and during presentation their teaching skill was assessed by using microteaching evaluation format. Feedback was given to each student from peer and from teacher regarding their presentation skill. The study was approved by the institutional ethical committee DMIMS(DU)/IEC/2018-19/7219 and the study was conducted in accordance with the ethical guidelines prescribed by central ethics committee on human research.

\section{RESULTS}

All students teaching skill was assessed by using microteaching evaluation format. The above table shows that $(0 \%)$ had poor level of teaching skill, (12\%) had average level of teaching skill, (48\%) had good level of teaching skill and (20\%) had very good level of teaching skill and no one had excellent level of teaching skill. The minimum score was 10 and the maximum score was 19.5 , the mean score for the test was $14.50 \pm 2.57$ and mean percentage of teaching skill 58\%.

Table 1. Assessment of teaching skill through microteaching $n=20$

\begin{tabular}{|c|c|c|c|c|}
\hline \multirow{2}{*}{$\begin{array}{c}\text { Level of teaching } \\
\text { skill }\end{array}$} & \multirow{2}{*}{$\begin{array}{l}\text { Score } \\
\text { Range }\end{array}$} & \multirow{2}{*}{ Percentage score } & \multicolumn{2}{|c|}{ Teaching skill score } \\
\hline & & & Frequency & Percentage \\
\hline Poor & $1-5$ & $0-20 \%$ & - & - \\
\hline Average & $6-10$ & $21-40 \%$ & 3 & $12 \%$ \\
\hline Good & $11-15$ & $41-60 \%$ & 12 & $48 \%$ \\
\hline Very Good & $16-20$ & $61-80 \%$ & 5 & $20 \%$ \\
\hline Excellent & $21-25$ & $81-100 \%$ & - & - \\
\hline \multicolumn{3}{|c|}{ Minimum } & \multicolumn{2}{|c|}{10} \\
\hline \multicolumn{3}{|c|}{ Maximum } & \multicolumn{2}{|c|}{19.5} \\
\hline \multicolumn{3}{|c|}{ Mean $\pm \mathrm{SD}$} & \multicolumn{2}{|c|}{$14.50 \pm 2.57$} \\
\hline \multicolumn{3}{|c|}{ Mean Percentage Score } & \multicolumn{2}{|c|}{$58 \%$} \\
\hline
\end{tabular}

Figure 1: Evaluation of Teaching skill of Nursing PG students through Microteaching

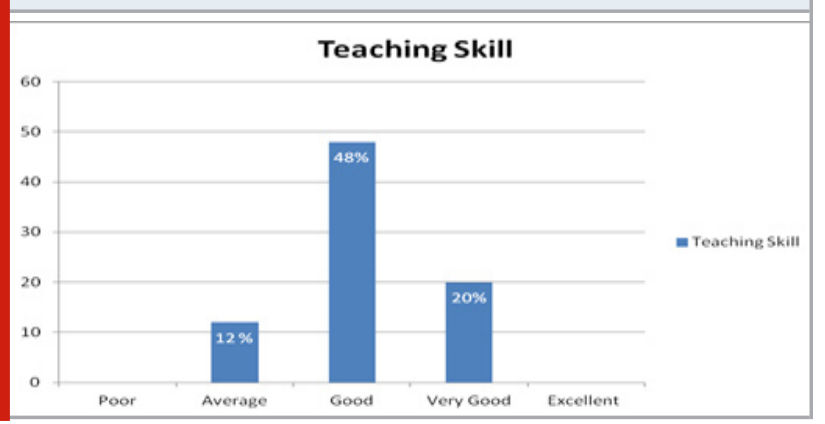

DISCUSSION

In this study the participants were evaluated on their microteaching evaluation format. They were evaluated by using microteaching evaluation format by the researcher. They get immediate feedback from the peers and researcher also. Feedback was given according to evaluation format of their presentation. Particular points were evaluated like content of presentation, face to face contact, positive reinforcement, participation of students and clarification of doubts. They accepted where they are lacking in teaching skill. On evaluation researcher found that some students were lacking in confidence, there was no group participation between the sessions. Some students did not complete within time limit. Some students were unable to maintain eye to eye contact with the class. A longitudinal study conducted by Vishal Indurkar to inculcate teaching skills and teaching behaviors in Post Graduate students to develop the interest in teaching of PG students. Total eight 1st year Post Graduate students were selected for this study. These students performed their teaching skill. Study completed in two sessions. Result shows that overall average percentage of was improved from $42 \%$ in session I to $59 \%$ in session II, observations were statically significant $\mathrm{p}=0.000$ (Paired 't' test).(“(PDF) MICROTEACHING -A TOOL USED TO IMPROVE TEACHING SKILLS AND 
TEACHING BEHAVIOR IN POST GRADUATE STUDENTS

| Editor International Journal of Clinical and Biomedical Resaerch (IJCBR) - Academia.edu,” n.d.).

Feedback from the peer was that they did not follow the rule for power point presentation. Spelling mistake was there. Mannerism was not good. Need to improve vocabulary. So here microteaching helps them to improve their teaching skill. Whatever feedback they got from peer and teacher they can show improvement in their lacking areas. According to Syed Sadat Ali, Rakesh Mittal microteaching also provides skilled supervision with an opportunity to get a constructive feedback to improve the content and methods of teaching.("Indian Journals," n.d.).

Findings of this study is match with another study done by Edwin G. Ralph this study has confirmed earlier research findings regarding the benefits of the microteaching technique in assisting individuals to develop their professional competence and confidence The aim of this study was to examine teacher-candidates perspectives on the effectiveness of microteaching as a method to help them acquire instructional skills, prior to their placement in the 16 -week extended practicum (internship) program in pre-K to grade 12 schools. The study finding shows that these new budding teachers get help from microteaching a teaching tool to improve their teaching. (Ralph, n.d.).

\section{CONCLUSION}

The present cross sectional descriptive study done to assess the teaching skill of post graduate nursing students. Findings show that microteaching helps the student teacher to improve teaching skill of post graduate nursing students. It helps to raise their confidence level. It helps how to use AV aids during class presentation. Feedback from the peer group helps them for motivation. Feedback helps them to improve their lacking areas improve their teaching ability. Microteaching is a teaching tool it can be implemented for improving teaching skill and it can be used by all the trainee teachers.

\section{REFERENCES}

Basavanthappa, B., 2009. Nursing education. Jaypee Brothers Medical Publishers, New Delhí.

how to improve teaching and learning in the classroom [WWW Document], 2020. . Vaist $\bigotimes$ Rinkodaros Etikos Kodeksas. URL https://www.vaistukodeksas.lt/ uncategorized/nxkk0vs9/ (accessed 7.15.21).

- How to teach? What are the qualities that should be present in a teacher (lecturer) ? Please share your own experience for effective teaching. [WWW Document], n.d. . ResearchGate. URL https://www.researchgate. net/post/How-to-teach-What-are-the-qualities-thatshould-be-present-in-a-teacher-lecturer-Please-shareyour-own-experience-for-effective-teaching (accessed 7.15.21).

Indian Journals [WWW Document], n.d. URL https:// www.indianjournals.com/ijor.aspx?target=ijor:ahhs\&tvo lume $=2$ tissue $=1 \mathrm{Etarticle}=$ editorial (accessed 7.15.21). JAYPEE BROTHERS: Book Details [WWW Document], n.d. URL https://www.jaypeebrothers.com/pgDetails. aspx ?cat=s\&tbook_id=9789389776942 (accessed 7.15.21).

Learning and Teaching Nursing (Fourth Edition) by B. Sankaranarayanan,B. Sindhu: New Softcover (2012) 4th edition. | BookVistas [WWW Document], n.d. URL https:// www.abebooks.com/Learning-Teaching-NursingFourth-Edition-Sankaranarayanan/10275339820/bd (accessed 7.15.21).

Outdoor Education School Science Camps California, 2013. . Outdoor Educ. Calif. URL https://dirtyclassroom. com/mock-teaching-jake-and-company/ (accessed 7.15.21).

(PDF) MICROTEACHING -A TOOL USED TO IMPROVE TEACHING SKILLS AND TEACHING BEHAVIOR IN POST GRADUATE STUDENTS | Editor International Journal of Clinical and Biomedical Resaerch (IJCBR) - Academia. edu [WWW Document], n.d. URL https://www.academia. edu/34938923/MICROTEACHING_--A_TOOL_USED_ TO_IMPROVE_TEACHING_SKILLS_AND_TEACHING_ BEHAVIOR_IN_POST_GRADUATE_STUDENTS (accessed 7.15.21).

Ralph, E.G., n.d. The Effectiveness of Microteaching: Five Years' Findings. Int. J. Humanit. Soc. Sci. Educ. 12.

Rimm-Kaufman, S., PhD, S, L., ilos, PhD, Virginia, U. of, n.d. Improving students' relationships with teachers [WWW Document]. https://www.apa.org. URL https:// www.apa.org/education-career/k12/relationships (accessed 7.15.21). 